\title{
The effectiveness of Cognitive Behavioral Psychotherapy in misophonia: A case report
}

\author{
Mizofonide Bilişsel Davranışçı Psikoterapinin etkinliği: Bir olgu sunumu
}

\author{
Ali Ercan Altınöz ${ }^{1}$, Nazlı Ece Ünal2 ${ }^{2}$ Şengül Tosun Altınöz ${ }^{3}$ \\ ${ }^{1}$ Assist. Prof.,Department of Psychiatry, Eskişehir Osmangazi University, Eskişehir, Turkey \\ ${ }^{2}$ M.D.,Department of Child and Adolescent Psychiatry, Eskişehir Osmangazi University, Eskişehir, Turkey \\ ${ }^{3}$ M.D.,Psychiatry Clinic, Eskişehir Yunus Emre State Hospital, Eskişehir, Turkey
}

\section{SUMMARY}

Misophonia is a condition that is triggered by certain sounds, which leads to unpleasant feelings such as anger, disgust, fear. Misophonia can severely affect patients' daily activities, social life, and interpersonal relationships. For these reasons, lately, misophonia is being recommended to be defined as a psychiatric disorder lately. Here we represent a case with misophonia and discuss the application of the cognitive behavioral psychotherapy as a treatment in an individual with misophonia. Although not being defined as a psychiatric diagnosis, many individuals are suffering from misophonia, and for these individuals, cognitive behavioral psychotherapy seems to be beneficial as a treatment option.

Key Words: Misophonia, cognitive behavioral psychotherapy, psychotherapy,

\section{ÖZET}

Mizofoni, bazı sesler tarafından tetiklenen; öfke, korku, iğrenme gibi hoş olmayan duygulara yol açan bir durumdur. Mizofoni hastaların günlük aktivitelerini, sosyal hayatını ve kişilerarası ilişkileri ciddi biçimde etkileyebilir. Bu gerekçelerle mizofoninin bir psikiyatrik bozukluk olarak tanımlanması son zamanlarda önerilmektedir. Bu makalede mizofonisi olan bir olgunun ve bilişsel davranışsal psikoterapi ile tedavisi tartışılmaktadır. Psikiyatrik bozukluk olarak tanımlanmamakla birlikte, birçok birey mizofoniden mustariptir ve bu bireyler için bilişsel davranışçı psikoterapi bir tedavi seçeneği olarak yararlı görünmektedir.

Anahtar Kelimeler: Mizofoni, bilişsel davranışçı psikoterapi, psikoterapi, 


\section{INTRODUCTION}

Misophonia is a condition that is triggered by certain sounds, which leads to unpleasant feelings such as anger, disgust, fear. Examples of triggering voices include voices such as eating and smacking sounds, swallowing sounds, breathing sounds in the mouth and the burr, gum chewing, the sound of eating sunflowers seed, pen snappers, clock ticks and door gratings $(1,2)$. In those with, misophonia fMRI studies have shown that the triggering sounds lead to reactions due to an excessively increased blood-oxygen level in the anterior insulat cortex (3). Misophonia can severely affect patients' daily activities, social life, and interpersonal relationships. Individuals with misophonia may not enter specific environments to avoid exposure to triggering sounds or may leave the environment or argue with the people making the noise. Symptoms and their dangerous consequences can negatively affect or restrict their life $(1,2,4)$. For all these reasons, publications are recommending the definition of misophonia as a psychiatric disorder (5).

It is stated that about $6 \%$ of the university students showed functional impairment associated with clinically significant symptoms of misophonia in China (6). In a thesis study conducted in our country, $79.9 \%$ of the sample was found to be disturbed by at least one of the voices mentioned above (1). In this case report, we try to discuss the application of the cognitive behavioral psychotherapy as a treatment in an individual with misophonia.

\section{CASE}

18 years old, female patient, medical faculty student. In the past, while living with his family, the patient had suffered any difficulties because her family could provide the optimum conditions for studying. However, after starting the medical school, she left his family and started to stay in a student hostel, and her complaints began. In this period, she noticed that she was not able to study in some specific settings due to some disturbing sounds.

Although she was a very successful student before, she applied to the psychiatric outpatient clinic for failing her first examination because she could not find a suitable place to study without disturbing the voices during her first term. She was complaining about the sound of the air conditioner. She was unable to study in the library because of that disturbing sound. Besides, she could not be able to concentrate on her studies when someone sits near to her with a drink. When she heard someone sipping, she felt extremely disturbed. She did not have any psychiatric disorder history. She did not mention any psychiatric disorders related to her family. No medical issues were reported as well.

In her mental status exam, she was oriented, cooperated. Her speech was goal-directed and fluent. She did not have any suicidal thought or delusions. Her mood was depressed. There seemed to be no psychiatric disorder according to DSM 5 in the patient.

As her academic functioning was affected negatively due to that sounds, she was considered to have misophonia. To measure the severety of misophonia, we used Misophonia Activation Scale (MAS), Misophonia Psychological Response Scale (MPRS), and Amsterdam Misophonia Scale (AMISOS). She had 6, 6, 11 points consequently.

We briefly informed the patient about misophonia, and suggested Cognitive Behavioral Psychotherapy (CBT) as a treatment option. General information on CBT was also mentioned. After patient's approval, six sessions of CBT were administered. The treatment plan was consisted of three part (2). The cognitive part was to challenge dysfunctional automatic thoughts, the behavioral part was to replace the maladaptive coping strategies with effective ones, and the physiological part was to support her coordinating her autonomic reactivity (2) . The main lines of CBT sessions were as follows:

\section{Session 1: Misophonia psychoeducation}

The patient was informed about misophonia. We used the only informative brochure in Turkish which was created by Öz and Kılıç. The patient was asked to describe the prevalence of the misophonia symptoms, the sort of symptoms that present, the 
hierarchy of disturbing sounds, the security-seeking behavior, and the areas she avoided to be in.

\section{Session 2: ABC model}

In this session, we informed the patient about the thought-belief-emotion-behavior cycle. We defined automatic thoughts, and also we discussed the consequences of the automatic thoughts in her life. The patient was asked to record automatic thoughts that trigger her emotions due to the sounds.

\section{Session 3: Syndrome formulation}

We formulated the symptoms of the patients and drew the vicious cycle suitable to her complaints in this session. This session was crucial for her treatment as she figured out that it was entirely not the voices, but mostly the automatic thoughts that disturbed her.

\section{Session 4: Autonomic Nervous System}

We informed the patient regarding the autonomic nervous system, besides we discussed the role of the parasympathetic nervous system in developing the soothing response. Now the patient seemed to be ready for the first behavioral test for a symptom that was in the middle of the patient's symptom hierarchy.

\section{Session 5: Behavioral Experiments}

We discussed the consequences of the behavioral experiments. The patient mentioned that she felt fine. She mentioned that she became aware of getting calm when she continued to study instead of leaving the environment immediately after hearing the disturbing sounds. She also mentioned that, after being aware of getting calm immediately, she executed some the behavioral experiments listed in her symptom list.

\section{Session 6: Cognitive remodeling}

At the beginning of this session, the patient stated that she had almost no complaints, that she could efficiently study in places where she could not study before, and that she could enter many places without security-seeking behaviors. She did all the experiments on the list all week long and did not encounter any difficulties. That was why she offered to end the CBT sessions. Then we conducted o session on cognitive remodeling. Besides, the interventions made during the six sessions were reviewed together.

At the end of the six sessions, the patient was invited to an evaluation interview. Her MAS, MPRS, and AMISOS scores were 2,2,4 consequently

\section{DISCUSSION}

This case represents the effectiveness of CBT on misophonia. The CBT techniques such as exposure and generating alternative thoughts were the key interventions for the patient $(7,8)$.

Misophonia is quite common in society although it is not recognized as a disorder. In our case, it appears that misophonia has limited the academic functioning of a medical student. Many individuals with misophonia report psychological distress and avoidance behaviors at the level of disrupting their occupational and social functioning $(1,2)$.

The literature related to misophonia treatment is lacking. The only research for misophonia treatment is an open trial reporting the effectiveness of CBT in misophonia (9). In this trial Schroder et al. combined some CBT techniques and converted them in a group CBT format and following treatment, nearly half of the patients showed a significant reduction of misophonia symptoms (9). There are also some case reports reporting effectiveness of CBT in misophonia (10). In these case reports, it is discussed that misophonia is a disorder that can be located in the OCD spectrum. Besides, in a recent study, misophonia was found to be strongly related to obsessive than to compulsive components of OCD (11). Consistent with the literature, our patient's maladaptive beliefs on the triggering sounds could be categorized as "overestimation of severity or probability of danger" and "perfectionism" which are mostly seen in OCD patients as 
well (12). So, cognitive interventions played a vital role for patient's treatment course.

Although misophonia has not yet been defined as an effective treatment modality, cognitive behavioral psychotherapy, which is effectively used in the treatment of many psychiatric disorders, has also been applied to this misophonia case and the patient's complaints have declined. In addition to an inherent predisposition to the emergence of misophonia, the role of inaccurate learning experiences also supports the view that cognitive-behavioral psychotherapy is useful in the treatment of misophonia $(1,4,13)$. Although a large part of the population may have indicated the intolerance of that kind of sounds, there are very few case reports in the literature that apply for treatment.

\section{CONCLUSION}

Although not being defined as a psychiatric disorder, many individuals are suffering from misopho-

\section{KAYNAKLAR}

1. Öz G. Ankara'da Mizofoni Belirtilerinin Yaygınlığı, Sosyodemografik Özellikler ve Ruhsal Belirtilerle İlişkisi [Tıpta Uzmanlık Tezi]. Ankara: Hacettepe Üniversitesi; 2015.

2. Bernstein RE, Angell KL, Dehle CM. A brief course of cognitive behavioural therapy for the treatment of misophonia: a case example. The Cognitive Behaviour Therapist. 2013;6.

3. Kumar S, Tansley-Hancock O, Sedley W, Winston JS, Callaghan MF, Allen M, et al. The Brain Basis for Misophonia. Curr Biol. 2017;27:527-33.

4. Schneider RL, Arch JJ. Letter to the editor: Potential treatment targets for misophonia. General Hospital Psychiatry, New York. 2015;37:370-1.

5. Taylor S. Misophonia: A new mental disorder? Med Hypotheses. 2017;103:109-17.

6. Zhou X, Wu MS, Storch EA. Misophonia symptoms among Chinese university students: Incidence, associated impairment, and clinical correlates. Journal of Obsessive-Compulsive and Related Disorders. 2017;14:7-12.

7. Akkoyunlu S, Türkçapar MH. A Technique: Generating Alternative Thoughts. Journal of Cognitive-Behavioral Psychotherapy and Research. 2013;2:53-9.

8. Akkoyunlu S, Türkçapar MH. A Technique: Exposure Therapy. Journal of Cognitive-Behavioral Psychotherapy and Research. 2013;2:121-8.

9. Schroder AE, Vulink NC, van Loon AJ, Denys DA. Cognitive behavioral therapy is effective in misophonia: An open trial. J Affect Disord. 2017;217:289-94.

10. McGuire JF, Wu MS, Storch EA. Cognitive-behavioral ther- nia, and for these individuals, CBT seems to be beneficial as a treatment option.

\section{Acknowledgement}

We obtained written consent from the patient for submission of the report. We would like to thank to Gökhan Öz for providing the materials.

Correspendence Adress: Assist. Prof. Ali Ercan Altinoz, Department of Psychiatry, Eskişehir Osmangazi University, Eskişehir, Turkey ercanaltinoz@hotmail.com apy for 2 youths with misophonia. The Journal of clinical psychiatry. 2015;76:573-4.

11. Cusack SE, Cash TV, Vrana SR. An examination of the relationship between misophonia, anxiety sensitivity, and obsessivecompulsive symptoms. Journal of Obsessive-Compulsive and Related Disorders. 2018;18:67-72.

12. Group OCCW. Cognitive assessment of obsessive-compulsive disorder. Behav Res Ther. 1997;35:667-81.

13. Dozier TH. Etiology, composition, development and maintenance of misophonia: A conditioned aversive reflex disorder. Psychological Thought. 2015;8:114-29. 